Article

\title{
Antioxidant Activity and Mechanism of Resveratrol and Polydatin Isolated from Mulberry (Morus alba L.)
}

\author{
Ziwei Li ${ }^{1}$, Xiaoman Chen ${ }^{1}$, Guo Liu ${ }^{1}$, Jun Li ${ }^{1}$, Jinglin Zhang ${ }^{2, *}$, , Yong Cao ${ }^{1}$ and Jianyin Miao ${ }^{1,2,3, *}$ \\ 1 Guangdong Provincial Key Laboratory of Nutraceuticals and Functional Foods, College of Food Science, \\ South China Agricultural University, Guangzhou 510642, China; liziwei@stu.scau.edu.cn (Z.L.); \\ e0554125@u.nus.edu (X.C.); liuguo@scau.edu.cn (G.L.); pretty_lj@163.com (J.L.); \\ caoyong2181@scau.edu.cn (Y.C.) \\ 2 Key Laboratory of Brewing Molecular Engineering of China Light Industry, Beijing 100048, China \\ 3 Guangxi Key Laboratory of Chemistry and Engineering of Forest Products, Guangxi University for \\ Nationalities, Nanning 530006, China \\ * Correspondence: zhangjinglin@btbu.edu.cn (J.Z.); miaojianyin8181@scau.edu.cn (J.M.); \\ Tel.: +86-10-68985382 (J.Z.); +86-20-85286234 (J.M.)
}

Citation: Li, Z.; Chen, X.; Liu, G.; Li, J.; Zhang, J.; Cao, Y.; Miao, J.

Antioxidant Activity and Mechanism of Resveratrol and Polydatin Isolated from Mulberry (Morus alba L.). Molecules 2021, 26, 7574. https:// doi.org/10.3390/molecules26247574

Academic Editors: Simona Fabroni, Krystian Marszałek and Aldo Todaro

Received: 7 November 2021

Accepted: 8 December 2021

Published: 14 December 2021

Publisher's Note: MDPI stays neutral with regard to jurisdictional claims in published maps and institutional affiliations.

Copyright: (c) 2021 by the authors. Licensee MDPI, Basel, Switzerland. This article is an open access article distributed under the terms and conditions of the Creative Commons Attribution (CC BY) license (https:// creativecommons.org/licenses/by/ $4.0 /)$.

\begin{abstract}
Natural stilbenes have unique physiological effects, such as anti-senile dementia, anticancer, anti-bacterial, lowering blood lipid, and other important biological functions, which have attracted great attention from scholars in recent years. In this study, two stilbene compounds, resveratrol (RES) and polydatin (PD), were isolated from Mulberry (Morus alba L.), and their antioxidant activity and mechanism were investigated. The results showed that the contents of RES and PD in mulberry roots were 32.45 and $3.15 \mu \mathrm{g} / \mathrm{g}$, respectively, significantly higher than those in mulberry fruits $(0.48$ and $0.0020 \mu \mathrm{g} / \mathrm{g})$ and mulberry branches $(5.70$ and $0.33 \mu \mathrm{g} / \mathrm{g})$. Both RES and PD showed high antioxidant potential by DPPH, ABTS free-scavenging methods, and ORAC assay, and provided protection against oxidative damage in HepG2 cells by increased catalase (CAT) activity, superoxide dismutase (SOD) activity, and Glutathione (GSH) content, and decreasing generation of reactive oxygen species (ROS), lactate dehydrogenase (LDH) level, and malondialdehyde (MDA) content. Therefore, RES and PD treatment could be effective for attenuating AAPH-induced oxidative stress in HepG2 cells. This study will promote the development and application of stilbene compounds. Furthermore, the RES and PD could be used as antioxidant supplements in functional foods, cosmetics, or pharmaceuticals, contributing to health improvement.
\end{abstract}

Keywords: mulberry; resveratrol; polydatin; extraction; antioxidant activity; mechanism

\section{Introduction}

There is an increasing demand for the beneficial effects of natural-source functional products and their biologically active molecules [1]. Functional ingredients such as polyphenols, bioactive peptides, probiotics, vitamins, and minerals are directly added to various foods to enhance their potential to prevent or control various diseases [2,3]. Among these bioactive compounds, plant-based functional foods have received significant attention in the food industry in recent times. More than 10,000 bioactive phytochemicals have been identified from plant-derived foods [4]. However, looking for some highly active phytochemicals from a wide range of sources is still the focus of research in the field of functional foods $[5,6]$.

Resveratrol (trans-3,5, $4^{\prime}$ - trihydroxy trans stilbene, RES) is a polyphenol compound found naturally in plant-based foods, which is considered as a potential functional-feed additive [7]. The basic structure of RES is composed of two phenol rings linked to each other by an ethylene bridge, which can be divided into two isomeric forms of trans resveratrol and cis resveratrol. It is usually found in plants in trans resveratrol form, and when taken orally, trans-resveratrol can be rapidly transformed to the biologically more active form 
of dihydro-resveratrol [8]. As RES has many potential health benefits for human health, such as anti-cancer, anti-inflammatory, anti-diabetic activities, hepato-protection, and inhibition of platelet aggregation $[9,10]$, its application as a biologically active ingredient has received extensive attention. In fact, RES is becoming a popular ingredient in dietary supplements and vitamin formulas, and it is expected to double in the global market in the next decade [11]. Furthermore, Polydatin $\left(3,4^{\prime}, 5\right.$-trihydroxystibene-3- $\beta$-mono-D-glucoside, PD), as the most abundant derivative of RES in nature, has attracted attention in the pharmaceutical and functional food industries ascribed to its higher oral bioavailability [12]. Moreover, in nature, PD tends to be more abundant than RES [13]. Therefore, there are many studies devoted to converting PD into RES, but ignore the functional properties of PD compounds [14]. It is worth noting that PD also performs well in many biological functions, such as anti-atherosclerosis [15], improving heart function [16], reducing cholesterol [17], and protecting against liver injury [18]. Moreover, PD has high water solubility and metabolic stability [19]. Among the numerous pharmacological effects, antioxidant effect is undoubtedly the most important. As antioxidant activity is related to a variety of physiological and metabolic activities, it is the most important prevention mechanism of the human body [20]. However, the extraction of natural RES and PD from plant resources and the comparative analysis of their activities have rarely been reported.

In the present study, RES and PD were isolated and identified from Mulberry (mulberry fruits, mulberry branches, and mulberry roots). The antioxidant activities of RES and PD were comprehensively evaluated by in vitro chemical and cell models. Finally, through establishing a cellular oxidative stress model induced by AAPH, the antioxidant protection mechanisms of RES and PD were studied.

\section{Results}

\subsection{Separation and Identification of RES and PD}

The extracts of RES and PD were firstly extracted from mulberry fruits, mulberry branches, and mulberry roots, respectively. Then, taking RES and PD standards as analytical references, the extracts were further separated and analyzed by high-performance liquid chromatography (HPLC). The chromatogram of the RES and PD standards were firstly observed and their retention time was $22.466 \mathrm{~min}$ (Figure 1a) and $11.529 \mathrm{~min}$ (Figure 1b), respectively. By comparing with the retention time of the RES and PD standards, the RES and PD were further purified from the extracts of mulberry fruits (Figure 1c), mulberry branches (Figure 1d), and mulberry roots (Figure 1e). The contents of RES were calculated, and we were surprised to find that RES in mulberry roots $(32.45 \mu \mathrm{g} / \mathrm{g})$ was the highest, which was 5.7 times and 68.2 times that in mulberry branches $(5.70 \mu \mathrm{g} / \mathrm{g})$ and mulberry fruits $(0.48 \mu \mathrm{g} / \mathrm{g})$ (Table 1). Similarly, the content distribution of PD in Mulberry was also measured. We found that the content of PD in mulberry roots $(3.15 \mu \mathrm{g} / \mathrm{g})$ was the highest, which was 9.6 times and 1576.7 times that in mulberry branches $(0.33 \mu \mathrm{g} / \mathrm{g}$ and mulberry fruits $(0.0020 \mu \mathrm{g} / \mathrm{g})$ (Table 1). Interestingly, RES and PD were most abundant in mulberry roots, and the content of RES was significantly higher than that of PD, which was 10.3 times that of PD.

Table 1. Distribution of RES and PD compounds content extracted from mulberry fruits, mulberry branches, and mulberry roots.

\begin{tabular}{cccc}
\hline Natural Stilbenes & $\begin{array}{c}\text { Mulberry Fruits } \\
(\boldsymbol{\mu g} / \mathbf{g})\end{array}$ & $\begin{array}{c}\text { Mulberry Branches } \\
(\boldsymbol{\mu g} / \mathbf{g})\end{array}$ & $\begin{array}{c}\text { Mulberry Roots } \\
(\boldsymbol{\mu g} / \mathbf{g})\end{array}$ \\
\hline RES & $0.48 \pm 0.0030^{\mathrm{a}}$ & $5.70 \pm 0.34^{\mathrm{c}}$ & $32.45 \pm 1.72^{\mathrm{d}}$ \\
PD & $0.0020 \pm 0.0028^{\mathrm{b}}$ & $0.33 \pm 0.028^{\mathrm{a}}$ & $3.15 \pm 1.52^{\mathrm{c}}$ \\
\hline
\end{tabular}

Note: Different letters indicate statistically significant differences $(p<0.05)$ among different groups. 

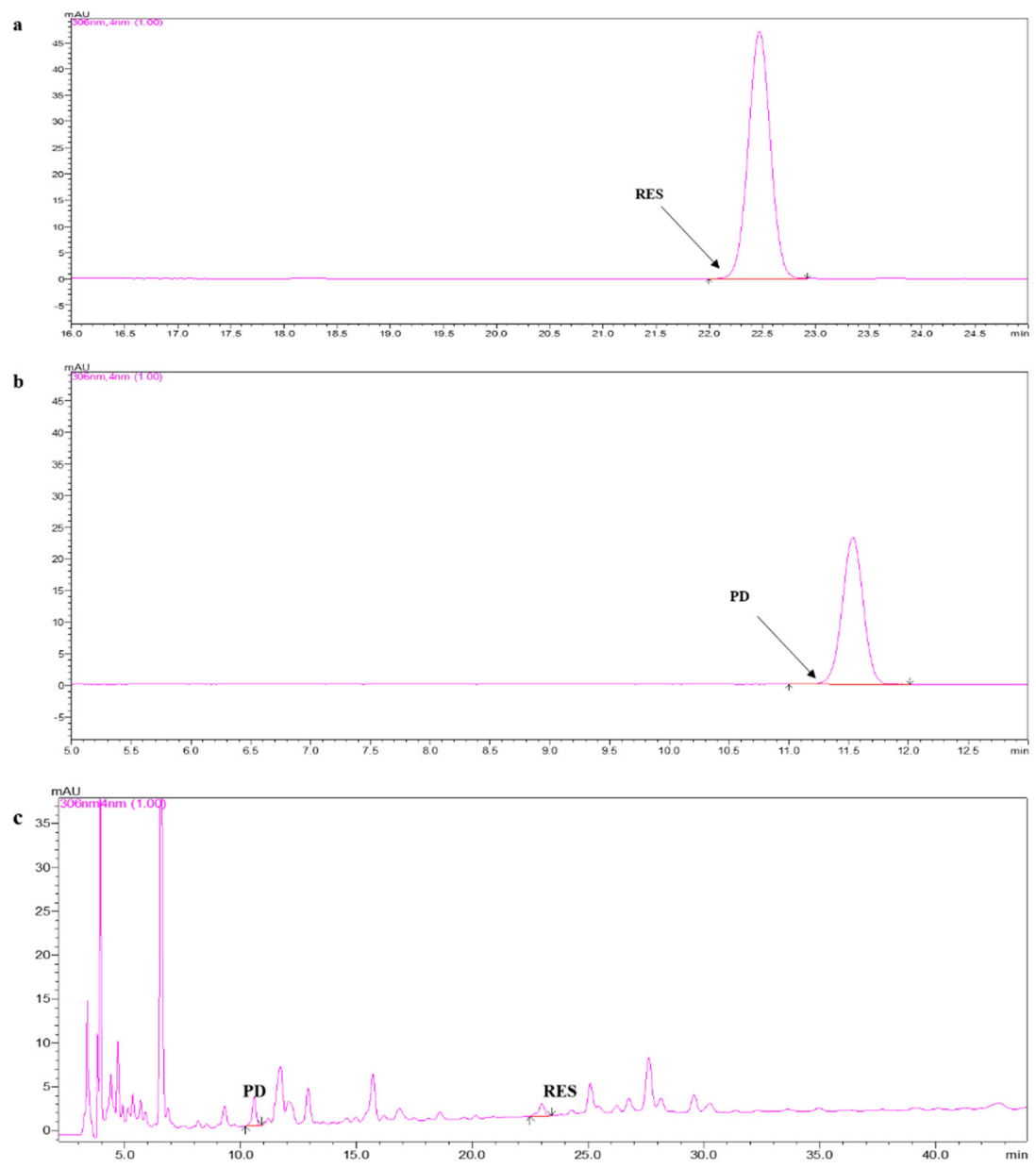

d
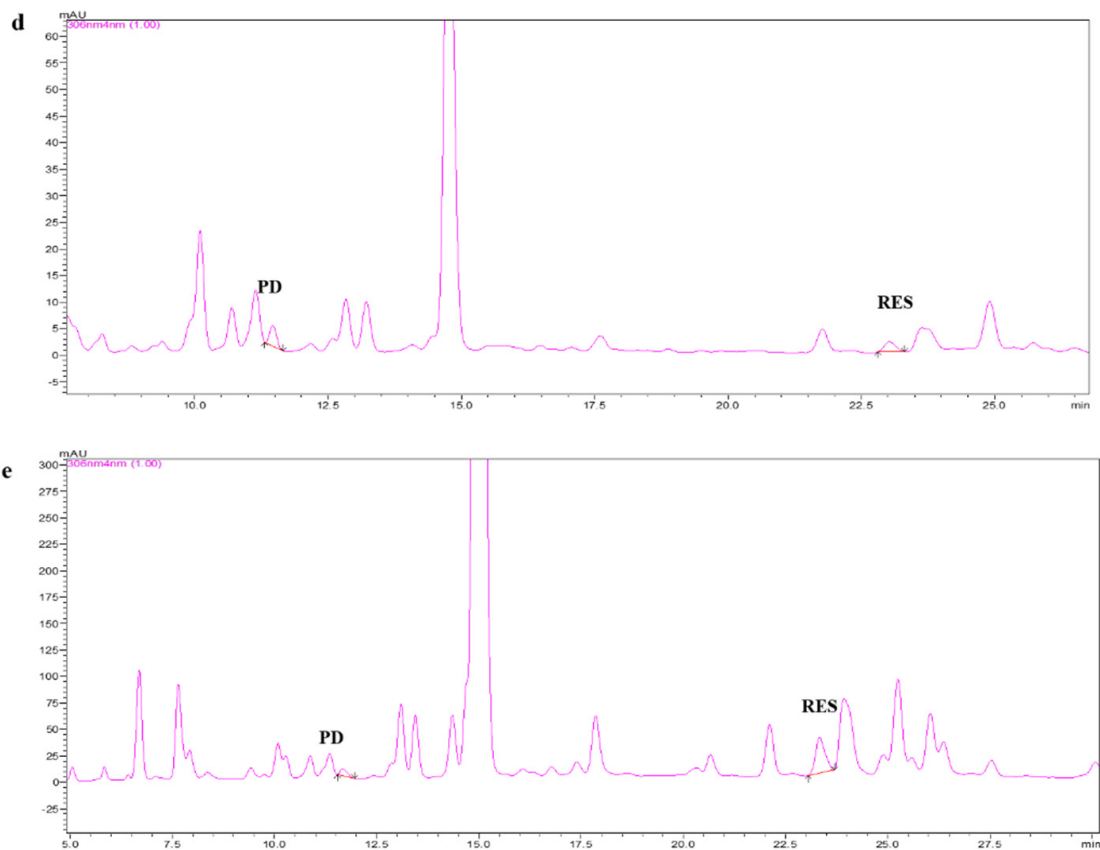

Figure 1. Isolated and purified RES and PD from mulberry fruits, mulberry branches, and mulberry roots. (a) The HPLC chromatogram of the RES standard compound. (b) The HPLC chromatogram of the PD standard compound. (c) The HPLC chromatogram of the RES and PD from mulberry fruits. (d) The HPLC chromatogram of the RES and PD from mulberry branches. (e) The HPLC chromatogram of the RES and PD from mulberry roots. 
Based on the above analysis, RES and PD from mulberry roots were further identified by UHPLC-ESI-MS/MS (Figure 2). The fingerprint mass spectra of RES and PD standards were obtained for the first time (Figure $2 a, b$ ), which can be used as a reference for the identification of RES and PD from mulberry roots. It can be seen from Figure $2 \mathrm{~d}$ that the precursor ion peak $[\mathrm{M}-\mathrm{H}]^{-}$of PD was detected at $m / z 389.0$, and its product ion fragment at $m / z$ 227.0. Furthermore, the precursor ion peak $[\mathrm{M}-\mathrm{H}]^{-}$of RES was detected at $m / z 227.0$, and its product ion fragment at $m / z 143.0$ and $m / z$ 184.9. (Figure 2e). Convincingly, these spectral data were consistent with those of the standards, and are also consistent with the data described in the literature [21,22]. This means that RES and PD were successfully isolated and identified from mulberry root.

\subsection{In Vitro Antioxidant Activities}

\subsubsection{DPPH Free Radical-Scavenging Activity}

The DPPH free radical-scavenging activities of the RES and PD are shown in Figure 3a. Both samples showed DPPH radical-scavenging activity in a dose-dependent manner. The RES showed higher inhibition ability of DPPH free radical oxidation than PD, suggesting that RES had higher antioxidant activity. The scavenging rate of RES on DPPH free radicals increased from $29.56 \%$ to $75.63 \%$, an increase of 1.51 times. Furthermore, the scavenging rate of DPPH free radicals by PD increased from $20.54 \%$ to $55.80 \%$, an increase of 1.72 times. This shows that although the antioxidant activity of PD was not as strong as that of RES, when the same concentration was increased, the antioxidant activity of $\mathrm{PD}$ has a better enhancement effect. Based on the $\mathrm{IC}_{50}$ values, the antioxidant activities of RES $\left(\mathrm{IC}_{50}=15.54 \mu \mathrm{g} / \mathrm{mL}\right)$ and PD $\left(\mathrm{IC}_{50}=54.35 \mu \mathrm{g} / \mathrm{mL}\right)$ were weaker than Vitamin C $\left(\mathrm{IC}_{50}=6.35 \mu \mathrm{g} / \mathrm{mL}\right)$, but they were stronger than those of traditional medicine Pometia pinnata $\left(\mathrm{IC}_{50}=92 \mu \mathrm{g} / \mathrm{mL}\right)$ [23] and Lygodium circinnatum $\left(\mathrm{IC}_{50}=143.76 \mu \mathrm{g} / \mathrm{mL}\right)$ [24].

\subsubsection{ABTS Free Radical-Scavenging Activity}

This method was determined by evaluating the decolorization ability of some phenols and flavonoids from plants after reacting with ABTS free radicals [25]. The ABTS free radical-scavenging activities of RES, $\mathrm{PD}$, and Vitamin $\mathrm{C}$ are shown in Figure $3 \mathrm{~b}$. According to the results, all compounds examined showed dose-dependent $\mathrm{ABTS}^{++}$radical-scavenging activity, but RES exhibited higher $\mathrm{ABTS}^{+{ }^{+}}$radical-scavenging activities than the PD and Vitamin C. In addition, RES, PD, and Vitamin C exhibited $\mathrm{IC}_{50}$ values of 2.86, 13.44, and $5.18 \mu \mathrm{g} / \mathrm{mL}$, respectively. Compared with the results of DPPH, RES has a very different scavenging efficiency on ABTS free radicals, which may be caused by different mechanisms. In the DPPH experiment, the hydrogen supply capacity of a compound determines the scavenging effect of free radicals, while the scavenging effect of $\mathrm{ABTS}^{+}$is determined by the scavenging effect of proton free radicals by giving electrons [26]. Therefore, we speculate that RES plays an antioxidant role by removing a proton from the hydroxyl group and giving it to free radicals to form stable phenoxy groups. This view was supported by the research of Das, A. K et al. [27]. In addition, as a potent antioxidant, Camellia sinensis tea was also more sensitive to $\mathrm{ABTS}^{+}$scavenging ability than DPPH free radical-scavenging ability [28]. 

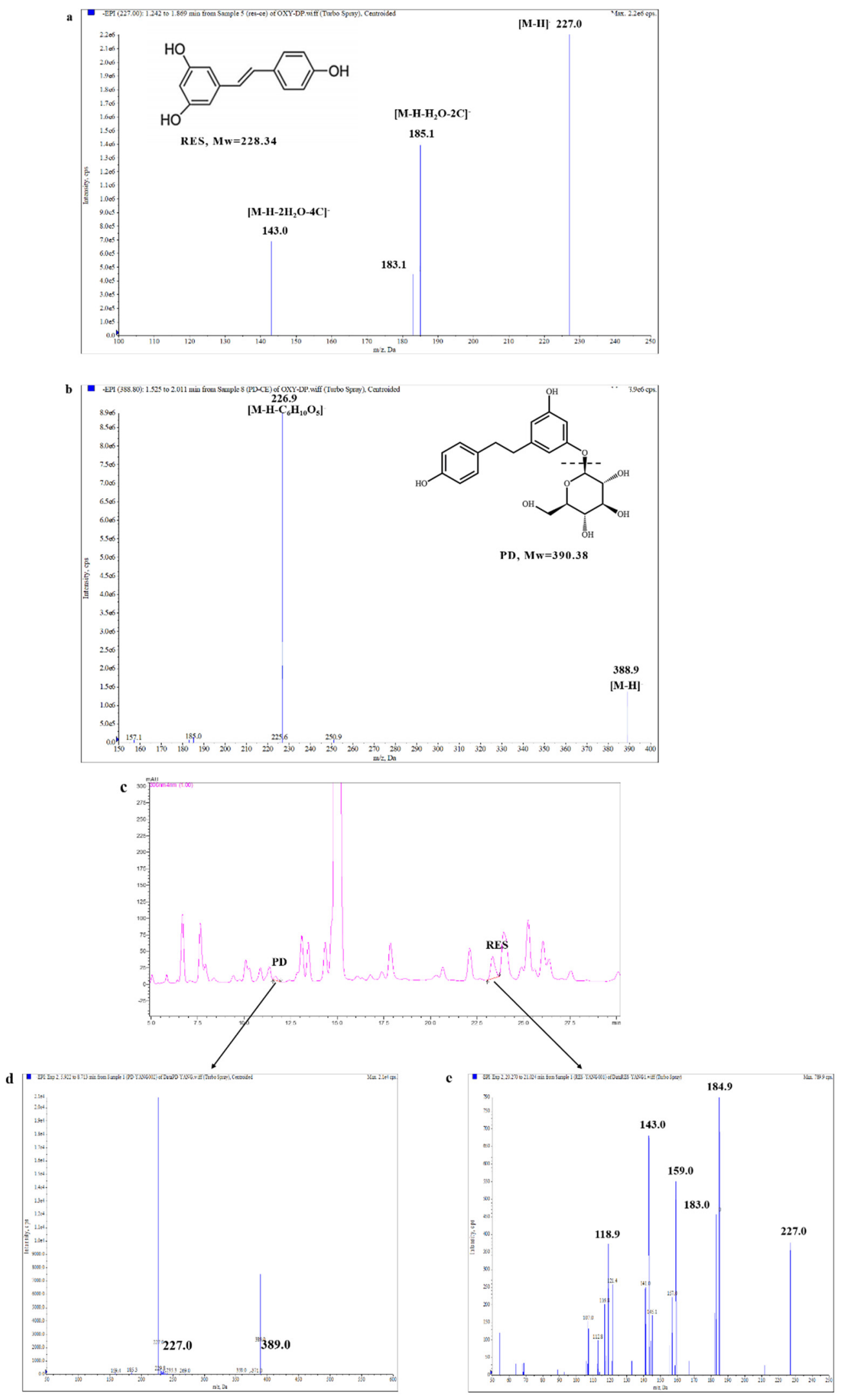

Figure 2. Identification of RES and PD from mulberry roots by UHPLC-ESI-MS/MS. (a) The fingerprint mass spectrum of RES standard. (b) The fingerprint mass spectrum of PD standard. (c) The HPLC chromatogram of the RES and PD from mulberry roots. (d) The MS2 spectrum of PD isolated from mulberry roots. (e) The MS2 spectrum of RES isolated from mulberry roots. 

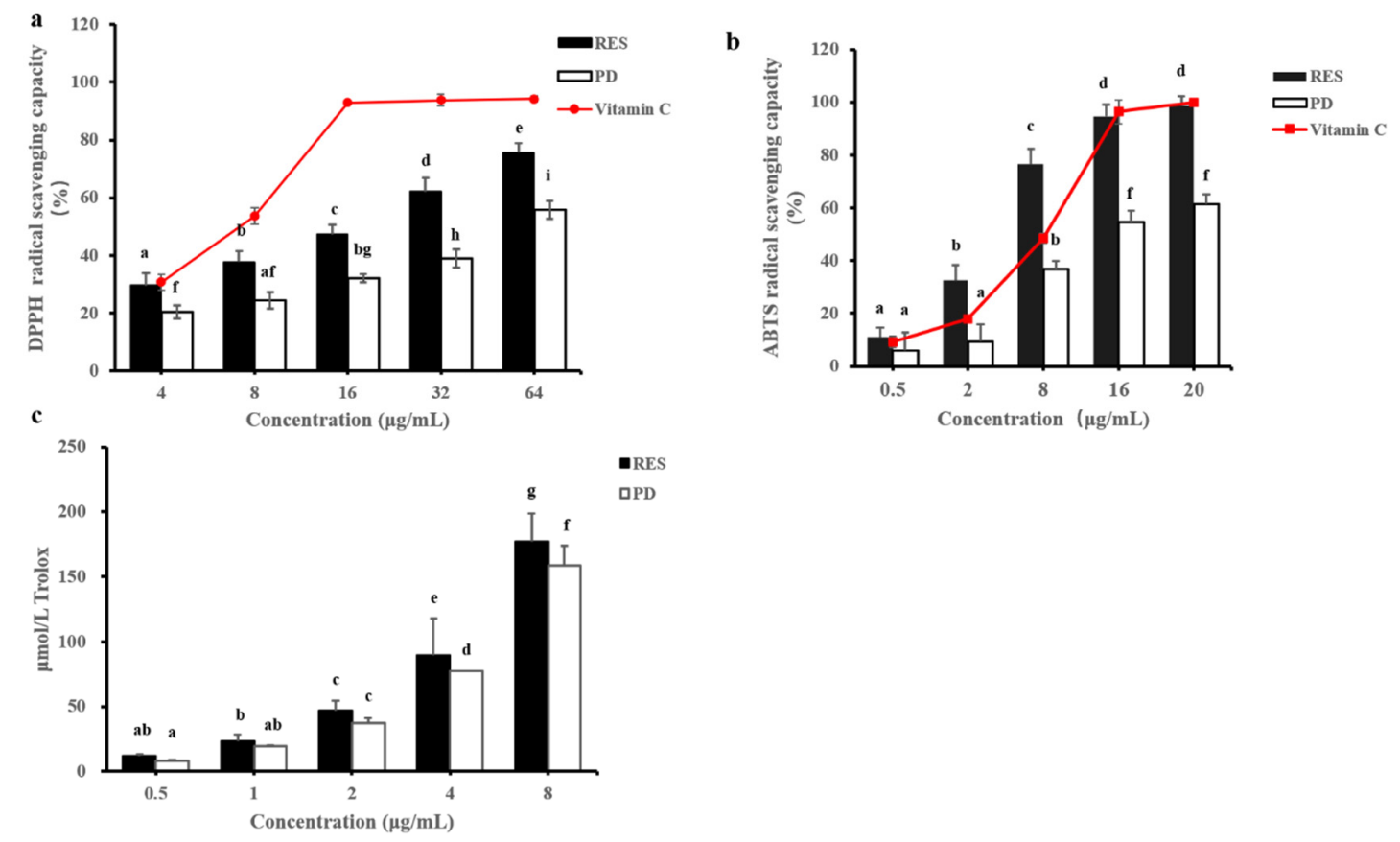

Figure 3. The in vitro antioxidant activities of RES and PD. (a) DPPH radical-scavenging activity. (b) ABTS radicalscavenging activity. (c) ORAC values. Data are shown as mean $\pm \mathrm{SD}(n=3)$. Different superscript characters indicate significant difference at $p<0.05$ level within the same row.

\subsubsection{ORAC (Oxygen Radical Absorption Capacity)}

The ORAC experiment is to determine the hydrophilic chain-breaking antioxidant capacity of the compound [29]. The method was highly related to biology because it uses physiological oxidant as reactant and reacts under physiological $\mathrm{pH}$ conditions [30,31]. The results for the assay are presented in Figure 3c. ORAC exhibited the same results as represented by DPPH and ABTS free radicals, showing a concentration-dependent manner, and the antioxidant activity of RES is always better than that of PD. When the RES concentration increased from $0.5 \mu \mathrm{g} / \mathrm{mL}$ to $8 \mu \mathrm{g} / \mathrm{mL}$, the corresponding Trolox concentration increased from $11.97 \mu \mathrm{mol} / \mathrm{L}$ to $177.19 \mu \mathrm{mol} / \mathrm{L}$, an increase of 14.80 times. The concentration of PD increased from $0.5 \mu \mathrm{g} / \mathrm{mL}$ to $8 \mu \mathrm{g} / \mathrm{mL}$, and corresponding Trolox concentration increased from $7.87 \mu \mathrm{mol} / \mathrm{L}$ to $158.98 \mu \mathrm{mol} / \mathrm{L}$, an increase of 20.20 times. This interesting phenomenon was consistent with the above DPPH assay results, indicating that the antioxidant activity of PD was more affected by concentration than RES. Furthermore, the ORAC value of each compound was expressed by Trolox equivalent (TE), and the ORAC value of RES was $23.12 \mu \mathrm{mol} \mathrm{TE} / \mathrm{g}$, and that of PD was $18.67 \mu \mathrm{mol} \mathrm{TE} / \mathrm{g}$. These data were similar to honey (18.48 $\mu \mathrm{mol} \mathrm{TE/g)} \mathrm{[32]} \mathrm{and} \mathrm{significantly} \mathrm{higher} \mathrm{than} \mathrm{the} \mathrm{ethanolic} \mathrm{leaf}$ extract of A. trifoliatusthe (9057.29 $\mathrm{mol} \mathrm{TE} / 100 \mathrm{~g})$ [33]. The result indicated that RES and PD exhibited very good antioxidant activity.

\section{3. $C A A$}

The cytotoxicity and antioxidant activity effects of RES and PD on HepG2 cells are shown in Figure 4. As shown in Figure $4 \mathrm{a}, 0-50 \mu \mathrm{g} / \mathrm{mL}$ of RES and PD have different degrees of toxic effects on cells. In general, the cytotoxicity of PD to cells was slight, and the cell viabilities of the two compounds below $2 \mu \mathrm{g} / \mathrm{mL}$ were more than $90 \%$, indicating that the concentration range does not affect the viability of cells. Therefore, $0-2 \mu \mathrm{g} / \mathrm{mL}$ RES and PD were selected to further evaluate the intracellular antioxidant activity. The two compounds at different concentrations showed the ability to quench peroxyl radicalinduced oxidation; furthermore, both exhibit a dose-dependent activity. In Figure $4 b$, the CAA unit of the RES was significantly increased from $3.60 \%$ to $56.84 \%$, and its $\mathrm{EC}_{50}$ 
and CAA values were calculated as $1.66 \mu \mathrm{g} / \mathrm{mL}$ and $331.80 \mu \mathrm{mol} \mathrm{QE} / 100 \mathrm{~g}$ compound, respectively. Similarly, the CAA unit of PD increased significantly from $4.48 \%$ to $28.43 \%$ (Figure 4c). In addition, the CAA unit of PD did not reach 50\% in the measured dose, so its $\mathrm{EC}_{50}$ value could not be calculated and CAA values were also not available. Therefore, consistent with the in vitro chemical antioxidant results, the antioxidant activity of RES in cells was also stronger than that of PD. Moreover, the cellular antioxidant effect of RES was significantly stronger than that of blueberry polyphenols [34] and cabbage [35], which were rich in anthocyanins.

\subsection{Protective Effects of RES and PD Compounds on HepG2 against AAPH-Induced Oxidative Stress}

AAPH could generate peroxyl radicals and be used as an initiator to induce the oxidative stress reaction of cells, which was a classic oxidative damage model [36]. In Figure 5 a, the cells were treated with different concentrations of AAPH to construct a cell oxidative damage model. After exposure to $0.8-20 \mathrm{mM} \mathrm{AAPH}$ for $24 \mathrm{~h}$, the cell viability rates were $79.56 \%, 76.68 \%, 77.46 \%, 77.18 \%, 74.46 \%, 49.37 \%$, and $25.70 \%$, respectively. According to the cell viability, we selected two different degrees of cell-damage effects for further experiments, which were treated with $0.8 \mathrm{mM}$ AAPH (cell viability rate was $79.56 \%$ ) and $18 \mathrm{mM} \mathrm{AAPH} \mathrm{(cell} \mathrm{viability} \mathrm{rate} \mathrm{was} 49.37 \%$ ).
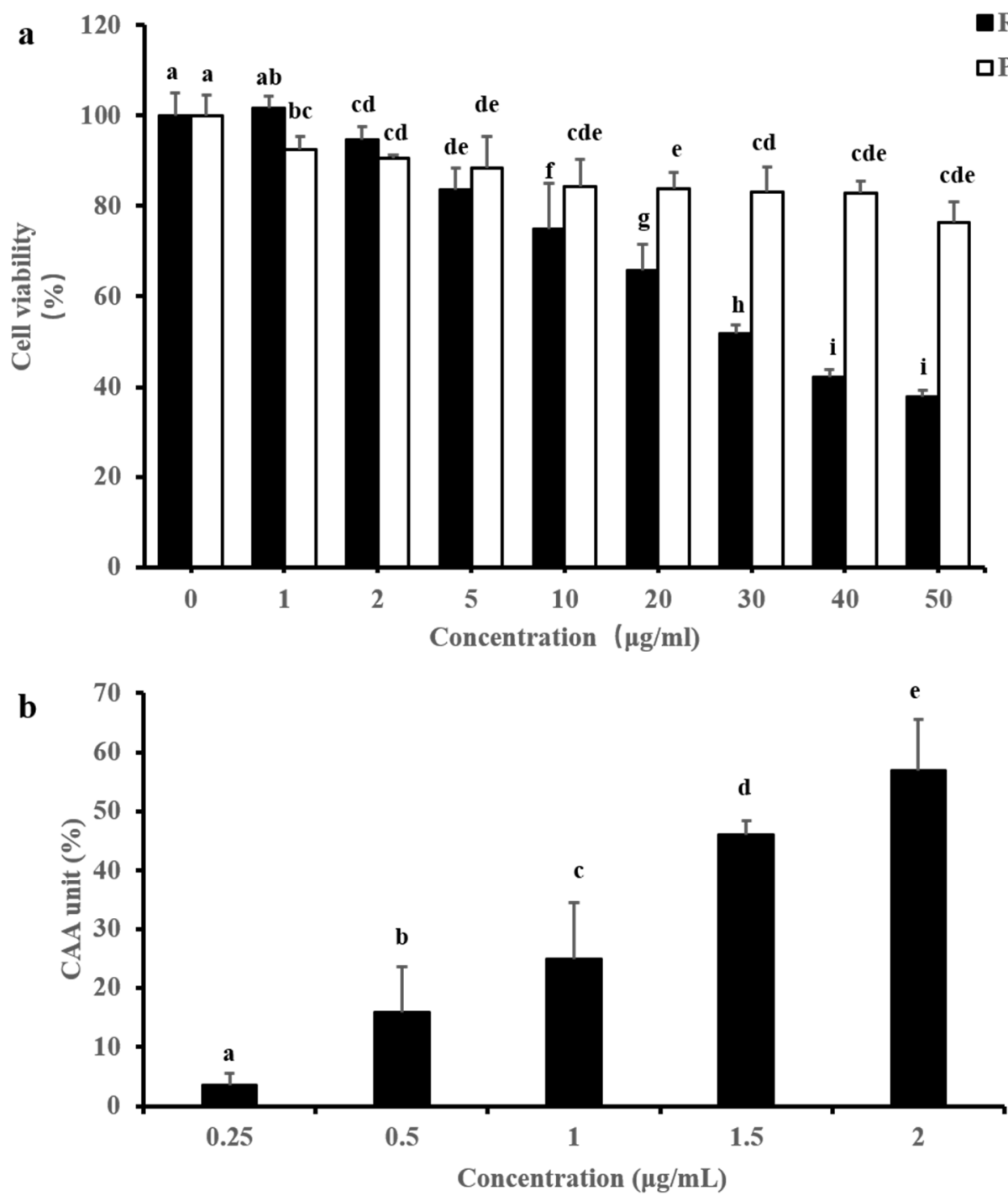

Figure 4. Cont. 


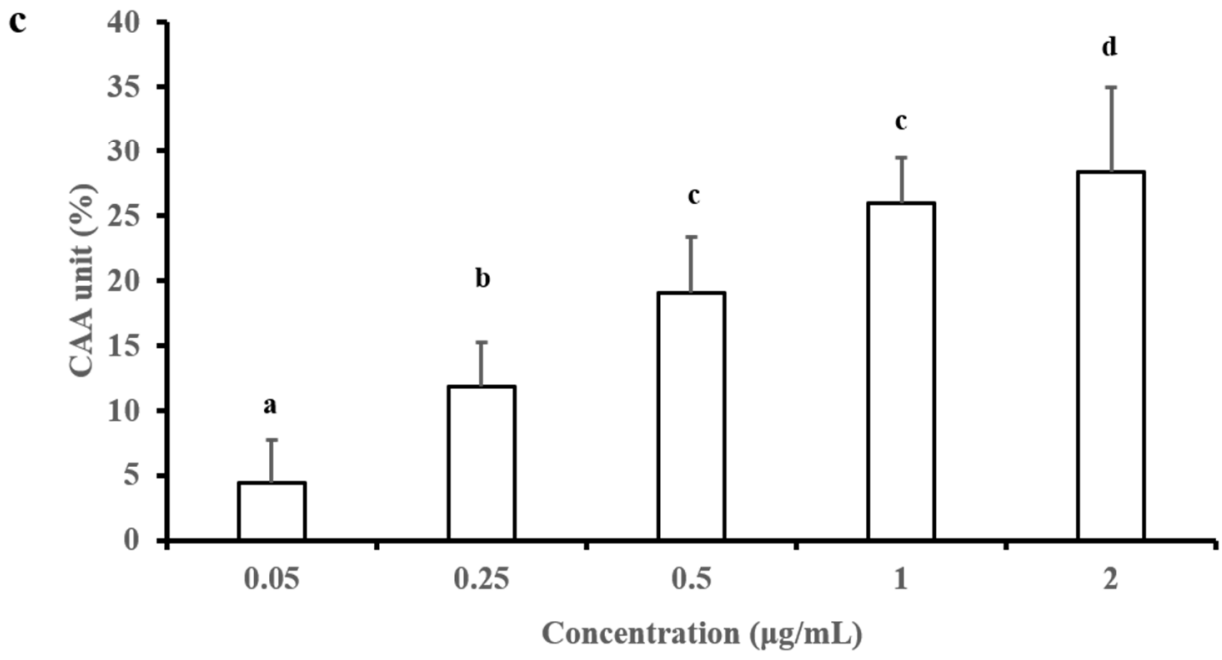

Figure 4. Determination of the cellular antioxidant activities of RES and PD. (a) The cytotoxic effects of RES and PD on HepG2 cells. (b) Cell antioxidant activity of RES at different concentrations. (c) Cell antioxidant activity of PD at different concentrations. Data are shown as mean $\pm \operatorname{SD}(n=3)$. Different letters on top of the bars denote significant difference $(p<0.05)$ among different concentrations.

As shown in Figure 5b, after exposure to $0.8 \mathrm{mM}$ AAPH for $24 \mathrm{~h}$, cell viability was significantly decreased compared to the control group. However, pretreatment with RES or PD attenuated AAPH-induced cell death. Compared with the damage group, the RES of $0.5-2 \mu \mathrm{g} / \mathrm{mL}$ significantly increased the cell viability rate from $79.65 \%$ to $99.02 \%$, $99.60 \%$, and $100.25 \%$, respectively. Similarly, compared with the damage group, the PD of $0.5-2 \mu \mathrm{g} / \mathrm{mL}$ significantly increased the cell viability rate from $79.65 \%$ to $101.33 \%, 101.90 \%$, and $105.10 \%$, respectively. These results indicate that pretreatment with $0.5-2 \mu \mathrm{g} / \mathrm{mL}$ RES or PD significantly alleviated $0.8 \mathrm{mM}$ AAPH-induced oxidative damage in HepG2 cells, and even restored to normal level. Moreover, the protective effects of RES and PD on the viability of $18 \mathrm{mM}$ AAPH-treated HepG2 cells were further evaluated. As shown in Figure $5 \mathrm{c}$, the HepG2 cells treated with $18 \mathrm{mM}$ AAPH for $24 \mathrm{~h}$ revealed about $50.72 \%$ cell viability rate. The cell survival rate was only $1.35 \%$ lower than that of the oxidative damage model, indicating that the model was stable. As shown in Figure 5c, pretreatment of the cells with RES or PD for $24 \mathrm{~h}$ followed by AAPH markedly increased the cells viability in a dose-dependent manner. In particular, $0.5,1$, and $2 \mu \mathrm{g} / \mathrm{mL}$ RES restored cell viability up to $56.39 \%, 58.25 \%$, and $59.27 \%$, respectively. Furthermore, $0.5,1$, and $2 \mu \mathrm{g} / \mathrm{mL}$ PD restored cell viability up to $52.89 \%, 54.43 \%$, and $60.40 \%$, respectively. Interestingly, based on the above results, we found that RES and PD showed better protective effects when the cells were treated to a lower degree of oxidative damage (cells were treated with $0.8 \mathrm{mM} \mathrm{AAPH}$ ). Surprisingly, in this degree of damage cells ( $0.8 \mathrm{mM}$ AAPH treatment), PD exhibited better protective effect than RES. Therefore, the protective mechanism of RES and PD against AAPH-induced oxidative stress needs further study, which may be related to the structural difference and the inhibition of reactive oxygen species (ROS) production $[37,38]$. 

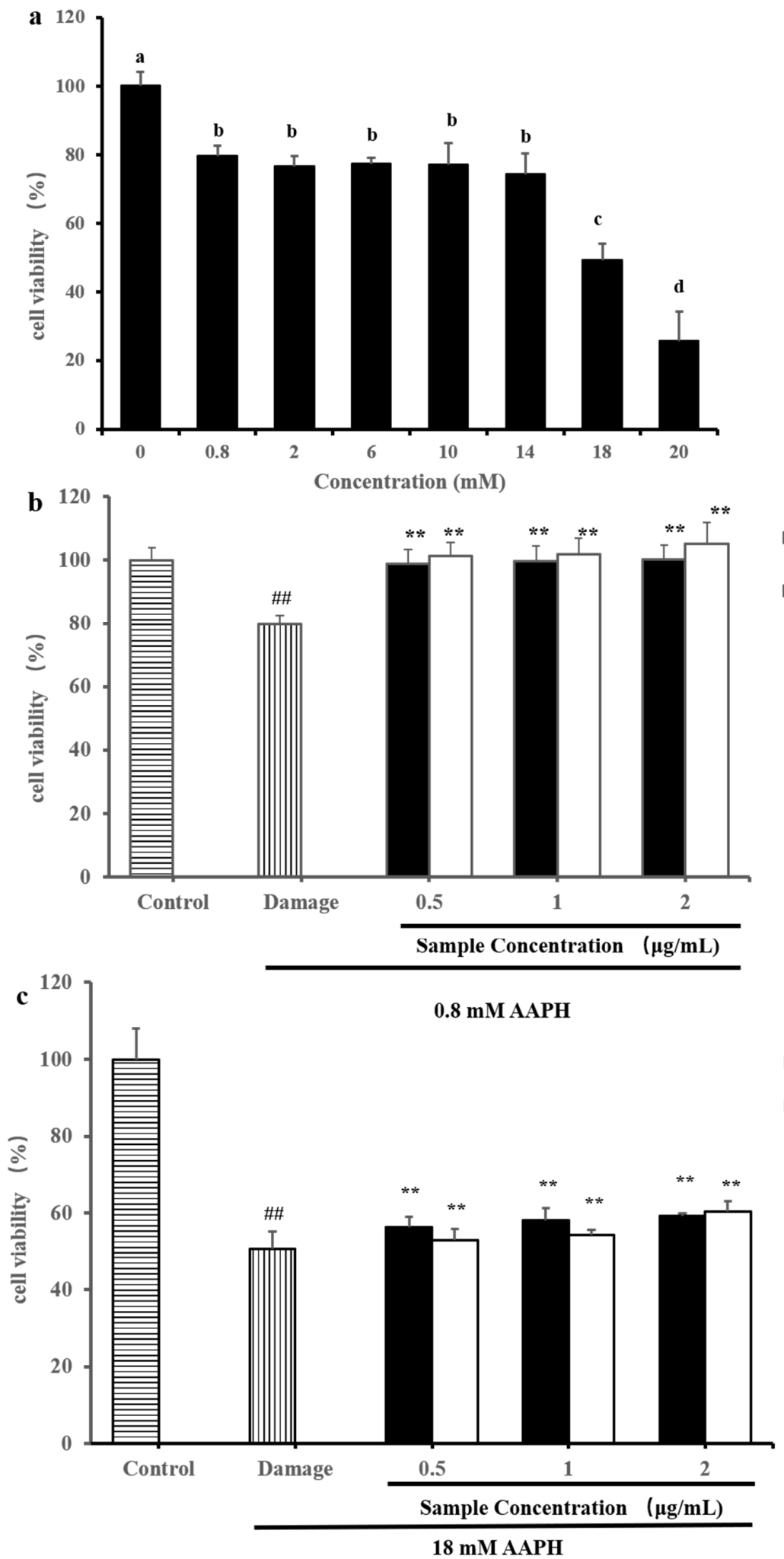

Figure 5. The protective effects of RES and PD against AAPH-induced oxidative stress. (a) Cell viability of AAPH-induced HepG2 cells. (b) The protective effects of RES and PD against $0.8 \mathrm{mM}$ AAPH-induced oxidative stress in HepG2 cells. (c) The protective effects of RES and PD against $18 \mathrm{mM}$ AAPH-induced oxidative stress in HepG2 cells. Data are shown as mean $\pm \mathrm{SD}(\mathrm{n}=3)$. Different letters on top of the bars denote significant difference $(p<0.05)$ among different concentrations. \#\# $p<0.01$ when compared to the control group; ${ }^{* *} p<0.01$ when compared to the damage group. 


\subsection{Effects of RES and PD on ROS Level in AAPH-Induced HepG2 Cell Damage}

The inhibitory effects of different RES and PD concentrations on ROS production in 0.8 mM AAPH-treated HepG2 cells was further determined (Figure 6). DCFH-Da was used to evaluate the ROS production during oxidative stress. DCFH-Da can be deacetylated in the cells and react with free radicals (mainly hydrogen peroxide) to form its fluorescent product, DCF $[39,40]$. The level of intracellular fluorescence was proportional to the degree of oxidation. In Figure 6A, the images (a) to (f) clearly reveal that AAPH in the cell induces the generation of ROS and produces fluorescence, while RES and PD reduce the production of ROS, and the fluorescence gradually weakens. As shown in Figure 6B, after $24 \mathrm{~h}$ of exposure to $0.8 \mathrm{mM}$ AAPH, relative fluorescence intensity in HepG2 cells significantly increased compared with those in the control group $(p<0.05)$. As expected, RES and PD pretreatment significantly attenuated the increases in the relative fluorescence intensity $(p<0.05)$. Compared with damage group, fluorescence intensity in RES-pretreated cells $(0.5$, 1 , and $2 \mu \mathrm{g} / \mathrm{mL}$ ) decreased by $11.15 \%, 11.42 \%$, and $13.19 \%$, respectively. Furthermore, PDpretreated cells $(0.5,1$, and $2 \mu \mathrm{g} / \mathrm{mL})$ reduced fluorescence intensity by $15.90 \%, 15.91 \%$, and $30.52 \%$, respectively. Hence, our results indicate that RES and PD pretreatment can protect cells from oxidative damage by inhibiting the production of ROS. It has been reported that regulation of ROS level is an important way for the bioactive dietary compounds of plants with antioxidant potential to exert antioxidant effect [41].

\subsection{Levels of Antioxidant Enzymes (SOD, LDH, CAT, and GSH) and MDA}

Intracellular antioxidant enzyme systems, including CAT and SOD, play an important role in the defense against oxidative stress [42]. The change in antioxidant enzyme activity can be used as a reliable biomarker of antioxidant response. GSH is the most important endogenous small-molecule antioxidant that protects cells from chemically induced cytotoxicity [43]. To further understand the protective effects exerted by RES and PD, we examined changes in the activities of CAT, SOD, and GSH (Figure 7). Treatment of HepG2 cells with $0.8 \mathrm{mM}$ AAPH for $24 \mathrm{~h}$ induced significant decreases in the activities of SOD and GSH content $(p<0.01)$. Treatment of HepG2 cells with $0.8 \mathrm{mM}$ AAPH for $24 \mathrm{~h}$ induced significant decreases in the activities of SOD and GSH content $(p<0.01)$. Compared to the damage group, pretreatment of the cells with RES reversed the AAPH-induced decreases in CAT, SOD, and GSH levels, and 0.5-2 $\mathrm{\mu g} / \mathrm{mL}$ RES increased CAT levels by $14.11 \%, 30 \%$, and $34.36 \%$ (Figure $7 \mathrm{a}$ ); increased SOD levels by $3.72 \%, 13.12 \%$, and $5.96 \%$ (Figure $7 \mathrm{~b}$ ); increased GSH levels by $7.38 \%, 10.24 \%$, and $11.39 \%$ (Figure 7c), respectively. Meanwhile, pretreatment with $\operatorname{PD}(0.5,1$, and $2 \mu \mathrm{g} / \mathrm{mL})$ increased CAT, SOD activity and GSH levels in a dose-dependent manner. Compared with the damage group, the CAT activity in the PDtreated cells significantly increased by $28.74 \%$ to $41.86 \%$ (Figure $7 \mathrm{a}$ ), the SOD activity and the GSH content increased by $11.67 \%$ to $28.48 \%$ (Figure $7 \mathrm{~b}$ ) and $5.59 \%$ to $6.89 \%$ (Figure $7 \mathrm{c}$ ), respectively. Therefore, these increased levels of CAT, SOD, and GSH may be conferred to protection of RES or PD against AAPH-induced oxidative stress in HepG2 cells.

MDA and lactate LDH are indicators of cell damage and oxidative stress [44]. As shown in the Figure $7 \mathrm{~d}$, the LDH level of damage group was significantly higher than that of the control group $(p<0.01)$, which indicated that the cells were injured by AAPH. Compared with the damage group, all samples could effectively inhibit increases in LDH in AAPH-induced HepG2 cells $(p<0.01)$. Pretreatment with $2 \mu \mathrm{g} / \mathrm{mL}$ RES and PD showed the strongest inhibitory effect, which reduced LDH levels by $35.89 \%$ and $33.33 \%$, respectively. In addition, compared with the damage group, all samples could also effectively inhibited increases in MDA in AAPH-induced HepG2 cells (Figure 7e). Pretreatment with $2 \mu \mathrm{g} / \mathrm{mL}$ PD showed the strongest suppressed the overproduction of MDA level decreasing to $5.64 \mathrm{nmol} / \mathrm{mg}$ protein. It is worth noting that PD was superior to RES in inhibiting MDA production, which once again indicates that PD can better protect cells from damage. Therefore, this can well explain the different protective effects of RES and PD compounds on HepG2 against AAPH-induced oxidative stress. The current results suggest that RES 
and PD were able to ameliorate oxidative stress and increase the expression of related antioxidant factors.

(A)
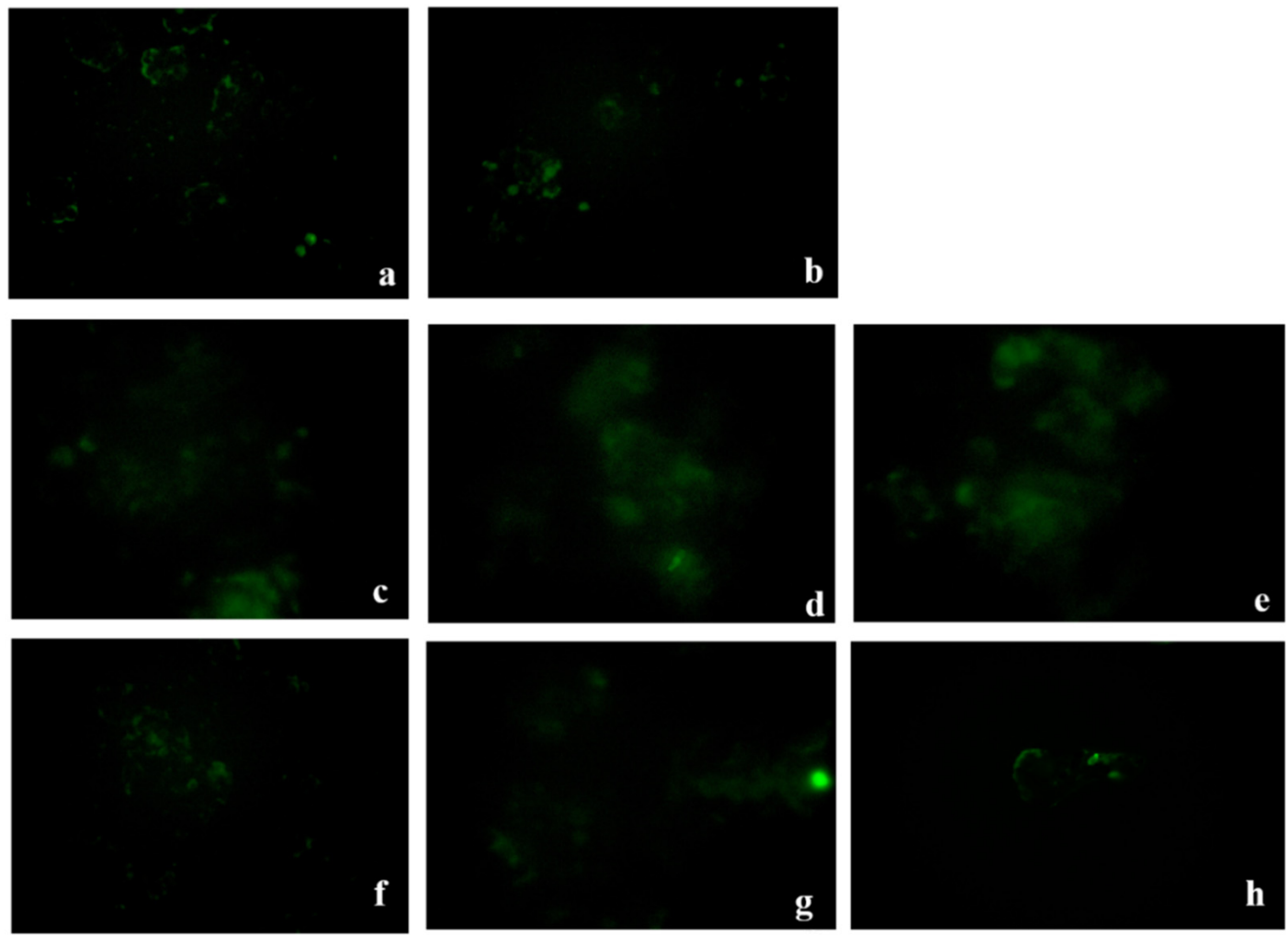

(B)

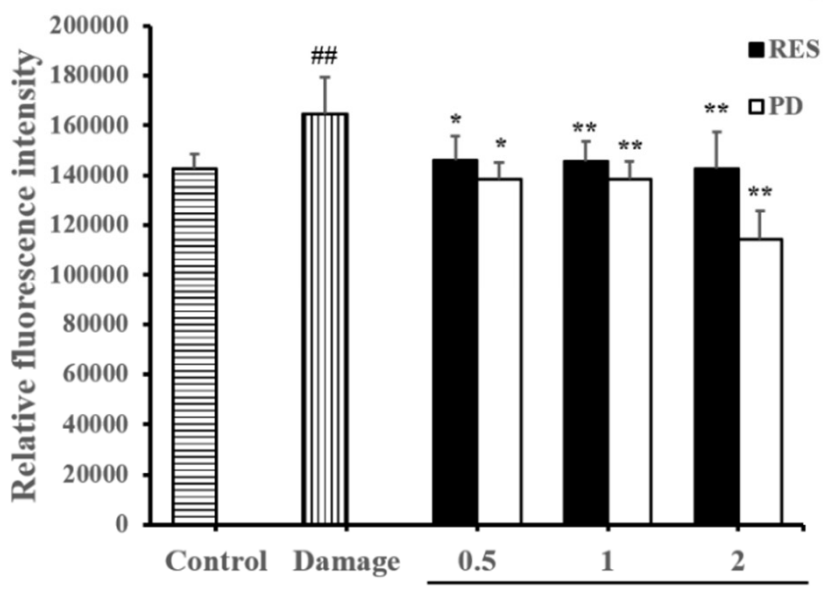

Sample concentration $(\mu \mathrm{g} / \mathrm{mL})$

0.8 mM AAPH

Figure 6. The intracellular ROS-scavenging abilities of RES and PD under conditions of AAPH-induced oxidative stress in HepG2 cells. (A): The fluorescence images of the cellular ROS-inhibitory effects of RES and PD in AAPH-induced HepG2 cells. (a) Control group without AAPH and pretreatment with samples. (b) Damage-group pretreatment with $0.8 \mathrm{mM}$ AAPH. Images (c-e) show the effects of $0.5,1$, and $2 \mu \mathrm{g} / \mathrm{mL}$ RES pretreatment add $0.8 \mathrm{mM}$ AAPH treatment, respectively. Images (f-h) show the effects of $0.5,1$, and $2 \mu \mathrm{g} / \mathrm{mL}$ PD pretreatment add $0.8 \mathrm{mM}$ AAPH treatment, respectively. (B): The fluorescence intensity value of the cellular ROS-inhibitory effects of RES and PD in AAPH-induced HepG2 cells. Data are shown as mean $\pm \mathrm{SD}(n=3)$. ${ }^{\# \#} p<0.01$ when compared to the control group; ${ }^{*} p<0.05$ when compared to the damage group, ${ }^{* *} p<0.01$ when compared to the damage group. 

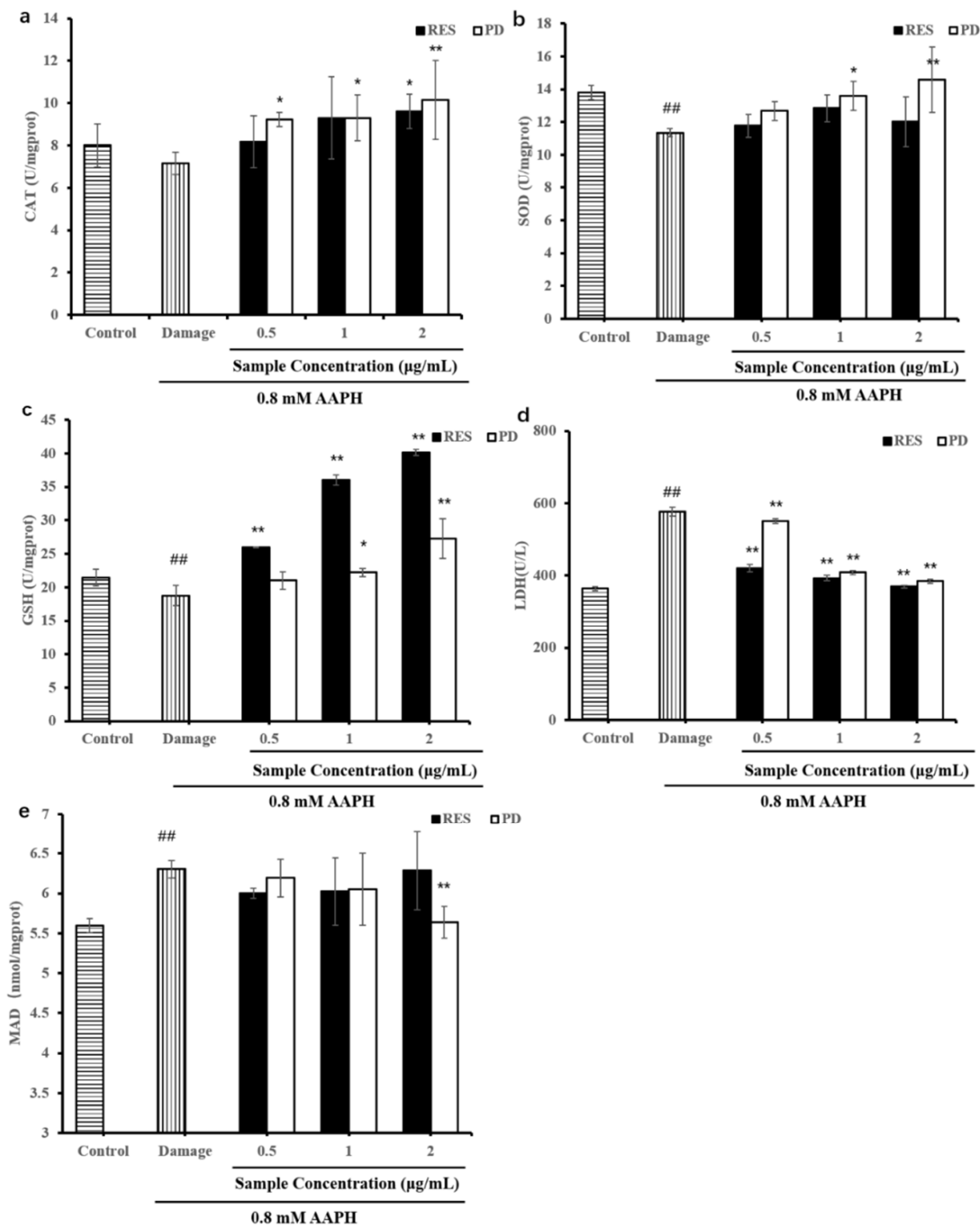

Figure 7. Effects of various concentrations of RES and PD on the AAPH-induced oxidative stress changes in the intracellular CAT (a), SOD (b), GSH (c), LDH (d), MDA (e) activities in HepG2 cells. Data are shown as mean $\pm \mathrm{SD}(n=3) .{ }^{\# \#} p<0.01$ when compared to the control group. ${ }^{*} p<0.05$ when compared to the damage group, ${ }^{* *} p<0.01$ when compared to the damage group.

\section{Materials and Methods}

\subsection{Chemicals and Materials}

HPLC-grade acetonitrile and phosphoric acid were obtained from Sigma Chemical Co. (St. Louis, MO, USA). The resveratrol and polydatin compounds used as standards were purchased from Shanghai Yuanye Bio-Technology Co., Ltd. (Shanghai, China). 2,2-azinobis (3-ethylbenzothiazoline- 6-sulfonic acid) (ABTS) and 2,2-diphenyl-l-picrylhydrazyl (DPPH) were purchased from Sigma-Aldrich ((Milano, Italy).). Cell culture reagents, including high-glucose medium (DMEM), fetal bovine serum (FBS), penicillin-streptomycin, and Hanks' balanced salt solution (HBSS), were purchased from Gibco Life Technologies (New York, NY, USA). 2',7'-dichlorofluorescin diacetate (DCFH-DA) and,2,2'-Azobis(2methylpropionamidine) (AAPH) were purchased from Sigma Chemical Co., Ltd. (St. Louis, MO, USA). Disposable $25 \mathrm{~cm}^{2}$ cell culture flasks and 96-well plates were obtained from Corning (Dalian, China). Organic membranes $(0.45 \mu \mathrm{m})$ and other chemicals of analytical grade were purchased from Kemiou (Tianjin, China). 


\subsection{Extraction of RES and PD}

The dried mulberry fruits, fresh mulberry branches, and mulberry roots were bought at Guangdong Baosang Yuan Health Food Co., Ltd. The plants were washed and dried in the oven $\left(50^{\circ} \mathrm{C}\right)$ until their weight was constant. Then, they were continuously pulverized in an Omni-mixer and ground to give 40-mesh-size powder.

The RES and PD were extracted from dried mulberry fruits, mulberry branches, and mulberry roots powders according to the previous method with a slight modification [45,46]. Based on the preliminary experiments, $3 \mathrm{~g}$ of powdered samples was added in $45 \mathrm{~mL}$ of $80 \%$ ethanol by the assistance of an ultrasonic bath for $60 \mathrm{~min}$ (two times, $30 \mathrm{~min}$ each time). The extracts were filtered with a Whatman filter paper and then the solvent was evaporated and concentrated to $10 \mathrm{~mL}$ by rotary evaporator. Afterwards, $\mathrm{NaCl}$ was added to the extract until it was saturated, and left to stand still at $4{ }^{\circ} \mathrm{C}$ for $10 \mathrm{~h}$ after filtration. Then, petroleum ether and ethyl acetate were added to the filtrate in order to remove impurities such as polysaccharides. After the extraction, the sample was dissolved in 50\% methanol and the obtained extract was collected and stored in darkness at $-20{ }^{\circ} \mathrm{C}$ for further analysis. The content of RES and PD was expressed in micrograms per gram of plant.

\subsection{Separation and Analysis of RES and PD}

The RES and PD were separated and quantified by HPLC (Shimadzu, Tokyo, Japan) and with an SPD-10A (V)vp ultraviolet detector. C18 column $(250 \mathrm{~mm} \times 4.6 \mathrm{~mm} \times 5 \mu \mathrm{m}$, Ultimate, Shanghai, China) was used for the separation and the mobile phase was consisted of $0.1 \%$ phosphoric acid in water (A) and acetonitrile (B) and the flow rate was $1 \mathrm{~mL} / \mathrm{min}$. The mobile phase was programmed consecutively in a linear gradient as follows: 0-20 min (17\% B-25\% B); $20-40 \mathrm{~min}(25 \% \mathrm{~B}-28 \% \mathrm{~B}) ; 40-75 \mathrm{~min}(28 \% \mathrm{~B}-45 \% \mathrm{~B})$; $75-85 \min (45 \%$ B-95\% B); 85-95 $\min (95 \%$ B-95\% B); and $95-100 \min (95 \%$ B-17\% B). The multi-wavelength detector was monitored at $305 \mathrm{~nm}$, the injection volume was $20 \mu \mathrm{L}$ for each sample solution and the column temperature was maintained at $25^{\circ} \mathrm{C}$.

The identification of the RES and PD was carried out using an AB Sciex QTRAP ${ }^{\circledR}$ 4500 UPLC-MS/MS (AB Sciex, Foster, CA, USA) triple quadrupole mass spectrometer equipped with an electrospray source operating in negative ionization mode. Multiplereactions monitoring (MRM) was employed to monitor the transitions of the molecular ion $\left([\mathrm{M}-\mathrm{H}]^{-}\right)$of RES at $m / z 227 \rightarrow 185$ and of PD at $m / z 388.8 \rightarrow 227$. The scan range was $m / z 100-500$. Typical mass spectrometric operated conditions: source temperature, $550{ }^{\circ} \mathrm{C}$; ion spray voltage, $-4500 \mathrm{~V}$; ion source gas $1,35 \mathrm{psi}$, ion source gas $2,60 \mathrm{psi}$, curtain gas, 40 , collision gas, medium, declustering potential (DP), -87.21 and $-96.18 \mathrm{~V}$; collision energy $(\mathrm{CE}),-25 \mathrm{~V}$ and $-10 \mathrm{~V}$.

\subsection{In Vitro Antioxidant Activities}

\subsubsection{DPPH Free Radical-Scavenging Activity}

The DPPH free radical-scavenging activity was determined according to the method described by Miao et al. [47] with slight modifications. Briefly, $100 \mu \mathrm{L}$ sample or standard (Vitamin C) with varying concentrations $(4,8,16,32$, and $64 \mu \mathrm{g} / \mathrm{mL}$ ) was added to the same volume of DPPH ethanolic solution $(0.15 \mathrm{mM})$. The mixture was then shaken vigorously and incubated at room temperature for $30 \mathrm{~min}$, and the absorbance was acquired at $517 \mathrm{~nm}$. Then, radical-scavenging activity was calculated as follows:

$$
\mathrm{PPH} \text { radical scavenging activity }(\%)=[1-(\mathrm{As}-\mathrm{Ab}) / \mathrm{Ac}] \times 100
$$

Where: As is the absorbance in the presence of the sample; $\mathrm{Ab}$ is the absorbance in the presence of the blank; $\mathrm{Ac}$ is the absorbance of the control; $\mathrm{IC}_{50}$ was determined by probit regression using IBM's Statistical Program for Social Sciences (SPSS, IBM, Armonk, NY, USA) analysis of variance (17.0). 


\subsubsection{ABTS Free Radical-Scavenging Activity}

The ABTS free radical-scavenging activity was determined by the method described by Miao et al. [47] with some modifications. First, $\mathrm{ABTS}^{+}$stock solution was prepared by reacting $7 \mathrm{mM}$ ABTS aqueous solution with $2.45 \mathrm{mM}$ potassium persulphate at room temperature in the dark for 12-16 h. The solution was then diluted with distilled water to achieve the absorbance of $0.7 \pm 0.02$ at $734 \mathrm{~nm}$. For the spectrophotometric measurement of the samples, $100 \mu \mathrm{L}$ of diluted $\mathrm{ABTS}^{+}$solution and $100 \mu \mathrm{L}$ of sample were mixed. After incubation at room temperature for $10 \mathrm{~min}$, the absorbance of the mixtures at $734 \mathrm{~nm}$ was measured. Vitamin $C$ was used as a reference. ABTS free radical-scavenging activity was calculated using the same formula as that used to measure DPPH radical-scavenging activity. IC $_{50}$ was determined by probit regression in SPSS (IBM, Armonk, NY, USA).

\subsubsection{ORAC Assays}

The ORAC assay was performed as previously described by Miao et al. [47] with some modifications. Briefly, $50 \mu \mathrm{L}$ RES or PD $(0.5,1,2,4,8,16 \mu \mathrm{g} / \mathrm{mL})$ and $100 \mu \mathrm{L}$ FL working solution ( $80 \mathrm{nM}$ final concentration) were mixed in the black 96-well plate and preincubated for $2-3 \mathrm{~min}$ at $37^{\circ} \mathrm{C}$. Then, $50 \mu \mathrm{L}$ APPH solution ( $153 \mathrm{mM}$ final concentration) was then added, and the fluorescence was recorded for $60 \mathrm{~min}$ at excitation and emission wavelengths of 485 and $530 \mathrm{~nm}$, respectively. Trolox, a water-soluble analogue of vitamin $\mathrm{E}$, was used as a reference. The final results were calculated using the differences in areas under the FL decay curves between the blank and a sample and ORAC values were expressed as $\mu \mathrm{mol}$ Trolox equivalent (TE)/ g of RES or PD compound ( $\mu \mathrm{mol} \mathrm{TE} / \mathrm{g}$ ).

\subsection{Cells Lines and Culture Conditions}

The HepG2 cells (human hepatoma cell line) originated from the Cell Bank of Chinese Academy of Sciences (Shanghai, China). HepG2 cells were cultured in the high-glucose medium (DMEM) supplemented with 10\% FBS, 1\% MEM non-essential amino acid solution, $100 \mathrm{U} / \mathrm{mL}$ penicillin, and $100 \mathrm{mg} / \mathrm{mL}$ streptomycin in a humidified atmosphere with $5 \%$ $\mathrm{CO}_{2}$ and $95 \%$ room air at $37^{\circ} \mathrm{C}$.

\subsubsection{MTT Assay}

The MTT assay was based on the protocol described by Miao et al. [47] with some modifications. Briefly, HepG2 cells were seeded in a 96-well plate of $1 \times 10^{4}$ cells/well and incubated for $24 \mathrm{~h}$. Then, the cells were treated with the samples at different concentrations $(1,2,5,10,20,30,40$, and $50 \mu \mathrm{g} / \mathrm{mL})$. The cells were then incubated for an additional $24 \mathrm{~h}$ at $37^{\circ} \mathrm{C}$. Furthermore, $100 \mu \mathrm{L}$ MTT $(0.5 \mathrm{mg} / \mathrm{mL}$ final concentration) was added and incubated at $37^{\circ} \mathrm{C}$ in the dark for $4 \mathrm{~h}$. Finally, the MTT solution was replaced with dimethyl sulphoxide (DMSO) to solubilize the formazan crystals, and the absorption value was determined at $490 \mathrm{~nm}$ by using a microplate reader (EnSpire, Perkin Elmer, Singapore).

\subsubsection{CAA}

Based on the method of Wolfe and Liu [39], HepG2 cells were seeded at $6 \times 10^{4} /$ well on a black 96-well plate in $100 \mu \mathrm{L}$ of DMEM, excluding the outside wells. After incubation at $37^{\circ} \mathrm{C}$ for $24 \mathrm{~h}$, the DMEM was discarded and the cells were washed with PBS, and treated for $1 \mathrm{~h}$ in triplicate with $100 \mu \mathrm{L}$ of RES or PD plus $25 \mu \mathrm{M}$ DCFH-DA dissolved in DMEM. After the medium was discarded and wells were washed again with PBS, $100 \mu \mathrm{L}$ of oxidant treatment medium $(600 \mu \mathrm{M}$ AAPH and HBSS with $10 \mathrm{mM}$ HEPES) was applied to the cells. Finally, the cellular fluorescence (excitation/emission, 485/535 nm) of the experimental samples (pretreated with samples, AAPH and DCFH-DA), control samples (pretreated with AAPH and DCFH-DA), and blank samples (pretreated with DCFH-DA) was measured every $5 \mathrm{~min}$ for $1 \mathrm{~h}$ on a microplate reader (EnSpire, Perkin Elmer, Singapore). Quercetin was used as a reference in each experiment, and the $\mathrm{EC}_{50}$ values of samples was expressed as mean and converted to CAA values using triplicate separate data. The CAA values were 
finally expressed as micromoles of quercetin equivalent (QE) per 100 micromoles of RES or PD $(\mu \mathrm{mol} \mathrm{QE} / 100 \mu \mathrm{mol})$.

\subsection{Measurement of Protect Effect against AAPH-Induced Oxidative Stress}

The AAPH-induced oxidative stress was determined according to the MTT method reported by Chou et al. [48] with some modifications. Firstly, cells were seeded in a 96-well plate of $2 \times 10^{4}$ cells/well and incubated for $24 \mathrm{~h}$. Then, the cells were treated with different concentrations of AAPH $(0.8,2,6,10,14,18,20 \mathrm{mM})$ and the cell viability was measured by MTT method. After successfully constructing a cell damage model, the cells were treated with the concentration of non-toxic samples for $24 \mathrm{~h}$, and then the suitable concentration of AAPH was added for another $24 \mathrm{~h}$. Finally, the cell viability was determined using MTT method as described above.

\subsection{ROS Level}

ROS generation was evaluated using the method described by Chou et al. [48] with some modifications. Cells were seeded in 12-well plates at a density of $2 \times 10^{4}$ cells $/ \mathrm{mL}$ in $2 \mathrm{~mL}$ complete media for $24 \mathrm{~h}$. Thereafter, the cells were cultured for $24 \mathrm{~h}$ with or without RES or PD at different concentrations $(0.5,1$, and $2 \mu \mathrm{g} / \mathrm{mL})$, followed by the addition of AAPH and continued culture at $37^{\circ} \mathrm{C}$ for $24 \mathrm{~h}$. Then, cells were incubated with $100 \mu \mathrm{L}$ of oxidation sensitive dye DCFH-DA $(10 \mu \mathrm{M})$ at $37^{\circ} \mathrm{C}$ for $30 \mathrm{~min}$ to monitor the changes in ROS. Finally, cells were washed twice with PBS and immediately measured its fluorescence intensity via a fluorescence microplate reader at $485 \mathrm{~nm}$ excitation and $535 \mathrm{~nm}$ emission and recorded with a fluorescence microscope.

\subsection{Measurement of GSH, MDA Levels and Cell Antioxidant Enzyme (LDH, SOD, and CAT)} Activity

Oxidative stress in these cells was induced by AAPH. A total of $3 \times 10^{6}$ HepG2 cells were placed in six-well plates. After $24 \mathrm{~h}$ of incubation, the medium was discarded and cells were treated with RES or PD at various concentrations $(0.5,1$, and $2 \mu \mathrm{g} / \mathrm{mL})$ for $24 \mathrm{~h}$. After incubation, the cells were treated with AAPH and incubated for $24 \mathrm{~h}$ at $37^{\circ} \mathrm{C}$ to induce oxidative stress. After the treatment, the supernatants were collected for further determination of $\mathrm{LDH}$, and cell pellets were collected for determination of CAT, SOD, GSH, and MDA immediately. The activities of LDH, SOD, CAT, GSH, and the content of MDA were determined using Assay Kits (Institute of Biological Engineering of Nanjing Jiancheng) according to the protocols. Protein contents were determined by Bicinchoninic Acid Kit (BCA) (BCA; Beyotime, Shanghai, China).

\subsection{Statistical Analysis}

All experiments were carried out at least three times, and the data are presented as mean \pm standard error (SE). Significant differences between measurements for the blank, control, and treated samples were analyzed using one-way analysis of variance (ANOVA), followed by Duncan's post-hoc test (SPSS 17.0).

\section{Conclusions}

This study reported the distribution and contents of RES and PD in Mulberry (Morus alba L.). The RES and PD extracted from Mulberry (Morus alba L.) confirm that mulberry roots have potential as a source of bioactive compounds and applied to functional food. Furthermore, RES and PD can scavenge various free radicals and enhance the antioxidant defense system of cells. Our discovery establishes insight in understanding the underlying molecular mechanism of RES and PD as antioxidants, and this protective mechanism can lead to the design and development of novel small molecules as potential functional active agents. 
Author Contributions: Conceptualization, J.M., J.Z. and Y.C.; methodology, Z.L., X.C. and J.M.; formal analysis, Z.L., X.C. and G.L.; investigation, Z.L. and J.L.; resources, J.M. and J.Z.; writing-original draft preparation, Z.L.; writing—review and editing, Z.L. and J.M.; supervision, J.M.; project administration, J.M. and J.Z.; funding acquisition, J.M. All authors have read and agreed to the published version of the manuscript.

Funding: This research was funded by the Open Project Program of the Key Laboratory of Brewing Mo-lecular Engineering of China Light Industry (BME-202005), the specific research project of Guangxi for research bases and talents (AD 18126005), the Natural Science Foundation of Guangdong province (2020A1515010371), and the Solid-state Fermentation Resource Utilization Key Laboratory of Sichuan Province (2019GTY003). The APC was funded by Jianyin Miao.

Institutional Review Board Statement: Not applicable.

Informed Consent Statement: Not applicable.

Data Availability Statement: Not applicable.

Acknowledgments: This work was supported by the Open Project Program of the Key Laboratory of Brewing Molecular Engineering of China Light Industry (BME-202005), the specific research project of Guangxi for research bases and talents (AD 18126005), the Natural Science Foundation of Guangdong province (2020A1515010371), and the Solid-state Fermentation Resource Utilization Key Laboratory of Sichuan Province (2019GTY003).

Conflicts of Interest: The authors declare no competing financial interest.

Sample Availability: The resveratrol and polydatin are available from the authors.

\section{References}

1. Gupta, E.; Mishra, P. Functional Food with some Health Benefits are so Called as Superfood-A Review. Curr. Nutr. Food Sci. 2020, 16. [CrossRef]

2. Saini, P.; Kumar, N.; Kumar, S.; Mwaurah, P.W.; Panghal, A.; Attkan, A.K.; Singh, V.K.; Garg, M.K.; Singh, V. Bioactive compounds, nutritional benefits and food applications of colored wheat: A comprehensive review. Crit. Rev. Food Sci. Nutr. 2020, 61, 3197-3210. [CrossRef]

3. Rakić, S.; Povrenović, D.; Tešević, V.; Simić, M.; Maletić, R. Oak acorn, polyphenols and antioxidant activity in functional food. J. Food Eng. 2006, 74, 416-423. [CrossRef]

4. Liu, R.H. Health-promoting components of fruits and vegetables in the diet. Adv. Nutr. 2013, 4, 3845-3925. [CrossRef]

5. Machado, A.; Geraldi, M.V.; do Nascimento, R.P.; Moya, A.; Vezza, T.; Diez-Echave, P.; Galvez, J.J.; Cazarin, C.B.B.; Marostica Junior, M.R. Polyphenols from food by-products: An alternative or complementary therapy to IBD conventional treatments. Food Res. Int. 2021, 140, 1-22. [CrossRef] [PubMed]

6. Singh, B.; Mal, G.; Sharma, D.; Sharma, R.; Antony, C.P.; Kalra, R.S. Gastrointestinal biotransformation of phytochemicals: Towards futuristic dietary therapeutics and functional foods. Trends. Food Sci. Technol. 2020, 106, 64-77. [CrossRef]

7. Yu, Q.; Fang, C.; Ma, Y.; He, S.; Ajuwon, K.M.; He, J. Dietary resveratrol supplement improves carcass traits and meat quality of Pekin ducks. Poult Sci. 2021, 100, 1-8. [CrossRef]

8. Williams, L.D.; Burdock, G.A.; Edwards, J.A.; Beck, M.; Bausch, J. Safety studies conducted on high-purity trans-resveratrol in experimental animals. Food Chem. Toxicol. 2009, 47, 2170-2182. [CrossRef]

9. Abdollahi, S.; Salehi-Abargouei, A.; Toupchian, O.; Sheikhha, M.H.; Fallahzadeh, H.; Rahmanian, M.; Tabatabaie, M.; Mozaffari-Khosravi, H. The Effect of Resveratrol Supplementation on Cardio-Metabolic Risk Factors in Patients with Type 2 Diabetes: A Randomized, Double-Blind Controlled Trial. Phytother. Res. 2019, 33, 3153-3162. [CrossRef]

10. Mirhadi, E.; Roufogalis, B.D.; Banach, M.; Barati, M.; Sahebkar, A. Resveratrol: Mechanistic and therapeutic perspectives in pulmonary arterial hypertension. Pharmacol. Res. 2021, 163,1-11. [CrossRef]

11. Huminiecki, L.; Atanasov, A.G.; Horbanczuk, J. Etiology of atherosclerosis informs choice of animal models and tissues for initial functional genomic studies of resveratrol. Pharmacol. Res. 2020, 156, 1-12. [CrossRef]

12. Montanari, S.; Davani, L.; Tumiatti, V.; Dimilta, M.; Gaddi, A.V.; De Simone, A.; Andrisano, V. Development of an UHPLC-diode arrays detector (DAD) method for the analysis of polydatin in human plasma. J. Pharmaceut. Biomed. 2021, 198, 1-7. [CrossRef]

13. Song, X.; Cui, L.; Li, J.; Yan, H.; Li, L.; Wen, L.; Geng, Y.; Wang, D. A novel bioreactor for highly efficient biotransformation of resveratrol from polydatin with high-speed counter-current chromatography. LWT-Food Sci. Technol. 2019, 103, 192-198. [CrossRef]

14. Fan, X.-H.; Wang, L.-T.; An, J.-Y.; Zhang, S.-D.; Cai, Z.-H.; Niu, L.-L.; Kou, P.; Yang, Q.; Meng, D.; Fu, Y.-j. Magnetically immobilized edible Bacillus natto for the biotransformation of polydatin to resveratrol and its bioactivity assessment. Ind. Crops Prod. 2021, 161, 1-7. [CrossRef] 
15. Peng, Y.; Xu, J.; Zeng, Y.; Chen, L.; Xu, X.L. Polydatin attenuates atherosclerosis in apolipoprotein E-deficient mice: Role of reverse cholesterol transport. Phytomedicine 2019, 62, 1-9. [CrossRef] [PubMed]

16. Du, Q.H.; Peng, C.; Zhang, H. Polydatin: A review of pharmacology and pharmacokinetics. Pharm. Biol. 2013, 51, 1347-1354. [CrossRef]

17. Zhao, X.J.; Yu, H.W.; Yang, Y.Z.; Wu, W.Y.; Chen, T.Y.; Jia, K.K.; Kang, L.L.; Jiao, R.Q.; Kong, L.D. Polydatin prevents fructoseinduced liver inflammation and lipid deposition through increasing miR-200a to regulate Keap1/Nrf2 pathway. Redox Biol. 2018, 18, 124-137. [CrossRef] [PubMed]

18. Zhang, H.; Yu, C.H.; Jiang, Y.P.; Peng, C.; He, K.; Tang, J.Y.; Xin, H.L. Protective effects of polydatin from Polygonum cuspidatum against carbon tetrachloride-induced liver injury in mice. PLOS ONE 2012, 7, e0046574. [CrossRef]

19. Platella, C.; Raucci, U.; Rega, N.; D'Atri, S.; Levati, L.; Roviello, G.N.; Fuggetta, M.P.; Musumeci, D.; Montesarchio, D. Shedding light on the interaction of polydatin and resveratrol with G-quadruplex and duplex DNA: A biophysical, computational and biological approach. Int. J. Biol. Macromol. 2020, 151, 1163-1172. [CrossRef]

20. Fleming, E.; Luo, Y. Co-delivery of synergistic antioxidants from food sources for the prevention of oxidative stress. J. Agric. Food Res. 2021, 3, 1-12. [CrossRef]

21. Wang, L.; Sang, M.; Liu, E.; Banahene, P.O.; Zhang, Y.; Wang, T.; Han, L.; Gao, X. Rapid profiling and pharmacokinetic studies of major compounds in crude extract from Polygonum multiflorum by UHPLC-Q-TOF-MS and UPLC-MS/MS. J. Pharm. Biomed. Anal. 2017, 140, 45-61. [CrossRef] [PubMed]

22. Ding, X.; Hou, X.; Gao, S.; Sun, M.; Lin, F.; Cai, G.; Xiao, K. Pharmacokinetics and bioavailability study of polydatin in rat plasma by using a LC-MS/MS method. Pak. J. Pharm. Sci. 2014, 27, 1931-1937.

23. Irawan, C.; Hanafi; Sulistiawaty, L.; Rochaeni, H.; Lestari, P.S. Evaluation of DPPH free radical scavenging activity of Pometia pinnata from Indonesia. Pharma Innov. J. 2017, 6, 403-406.

24. Saman, R.B.A.; Mokhtar, R.A.M.; Iqbal, M. Identification of Bioactive Compounds, Quantitative Measurement of Phenolics and Flavonoids Content, and Radical Scavenging Activity of Lygodium circinnatum. Trans. Sci. Technol. 2017, 4, 354-359.

25. MacDonald-Wicks, L.K.; Wood, L.G.; Garg, M.L. Methodology for the determination of biological antioxidant capacityin vitro: A review. J. Sci. Food Agric. 2006, 86, 2046-2056. [CrossRef]

26. Sanchez-Moreno, C. Review: Methods Used to Evaluate the Free Radical Scavenging Activity in Foods and Biological Systems. Food Sci. Technol. Int. 2002, 8, 121-137. [CrossRef]

27. Das, A.K.; Singh, V. Antioxidative free and bound phenolic constituents in botanical fractions of Indian specialty maize (Zea mays L.) genotypes. Food Chem. 2016, 201, 298-306. [CrossRef]

28. Sirichaiwetchakoon, K.; Lowe, G.M.; Eumkeb, G. The Free Radical Scavenging and Anti-Isolated Human LDL Oxidation Activities of Pluchea indica (L.) Less. Tea Compared to Green Tea (Camellia sinensis). Biomed. Res. Int. 2020, 2020, 1-12. [CrossRef] [PubMed]

29. Prior, R.L.; Wu, X.; Schaich, K. Standardized methods for the determination of antioxidant capacity and phenolics in foods and dietary supplements. J. Agric. Food Chem. 2005, 53, 4290-4302. [CrossRef] [PubMed]

30. Bisby, R.H.; Brooke, R.; Navaratnam, S. Effect of antioxidant oxidation potential in the oxygen radical absorption capacity (ORAC) assay. Food Chem. 2008, 108, 1002-1007. [CrossRef]

31. Dudonne, S.; Vitrac, X.; Ere, P.C.; Woillez, M.; Erillon, J.-M.M. Comparative Study of Antioxidant Properties and Total Phenolic Content of 30 Plant Extracts of Industrial Interest Using DPPH, ABTS, FRAP, SOD, and ORAC Assays. J. Agric. Food Chem. 2009, $57,1768-1774$.

32. do Nascimento, K.S.; Gasparotto Sattler, J.A.; Lauer Macedo, L.F.; Serna González, C.V.; Pereira de Melo, I.L.; da Silva Araújo, E.; Granato, D.; Sattler, A.; de Almeida-Muradian, L.B. Phenolic compounds, antioxidant capacity and physicochemical properties of Brazilian Apis mellifera honeys. LWT-Food Sci. Technol. 2018, 91, 85-94. [CrossRef]

33. Ganogpichayagrai, A.; Suksaard, C. Proximate composition, vitamin and mineral composition, antioxidant capacity, and anticancer activity of Acanthopanax trifoliatus. J. Adv. Pharm. Technol. Res. 2020, 11, 179-183. [CrossRef] [PubMed]

34. Jiao, X.; Li, B.; Zhang, Q.; Gao, N.; Zhang, X.; Meng, X. Effect of in vitro-simulated gastrointestinal digestion on the stability and antioxidant activity of blueberry polyphenols and their cellular antioxidant activity towards HepG2 cells. Int. J. Food Sci. Technol. 2018, 53, 61-71. [CrossRef]

35. Murador, D.C.; Mercadante, A.Z.; de Rosso, V.V. Cooking techniques improve the levels of bioactive compounds and antioxidant activity in kale and red cabbage. Food Chem. 2016, 196, 1101-1107. [CrossRef] [PubMed]

36. Wu, J.; Huo, J.; Huang, M.; Zhao, M.; Luo, X.; Sun, B. Structural Characterization of a Tetrapeptide from Sesame Flavor-Type Baijiu and Its Preventive Effects against AAPH-Induced Oxidative Stress in HepG2 Cells. J. Agric Food Chem. 2017, 65, 10495-10504. [CrossRef] [PubMed]

37. Kulkarni, A.P.; Mittal, S.P.; Devasagayam, T.P.; Pal, J.K. Oxidative stress perturbs cell proliferation in human K562 cells by modulating protein synthesis and cell cycle. Free Radic Res. 2009, 43, 1090-1100. [CrossRef]

38. Liao, W.; Ning, Z.; Chen, L.; Wei, Q.; Yuan, E.; Yang, J.; Ren, J. Intracellular antioxidant detoxifying effects of diosmetin on 2,2-azobis(2-amidinopropane) dihydrochloride (AAPH)-induced oxidative stress through inhibition of reactive oxygen species generation. J. Agric Food Chem. 2014, 62, 8648-8654. [CrossRef] [PubMed]

39. Wolfe, K.L.; Liu, R.H. Cellular Antioxidant Activity (CAA) Assay for Assessing Antioxidants, Foods, and Dietary Supplements. J. Agric. Food Chem. 2007, 55, 8896-8907. [CrossRef] 
40. Lee, S.H.; Han, J.S.; Heo, S.J.; Hwang, J.Y.; Jeon, Y.J. Protective effects of dieckol isolated from Ecklonia cava against high glucose-induced oxidative stress in human umbilical vein endothelial cells. Toxicol. In Vitro 2010, 24, 375-381. [CrossRef] [PubMed]

41. Grauzdyte, D.; Pukalskas, A.; Viranaicken, W.; El Kalamouni, C.; Venskutonis, P.R. Protective effects of Phyllanthus phillyreifolius extracts against hydrogen peroxide induced oxidative stress in HEK293 cells. PLoS ONE 2018, 13, e0207672. [CrossRef] [PubMed]

42. Rodgers, E.H.; Grant, M.H. The effect of the flavonoids, quercetin, myricetin and epicatechin on the growth and enzyme activities of MCF7 human breast cancer cells. Chem.-Biol. Interact. 1998, 116, 213-228. [CrossRef]

43. Kovacs-Nolan, J.; Rupa, P.; Matsui, T.; Tanaka, M.; Konishi, T.; Sauchi, Y.; Sato, K.; Ono, S.; Mine, Y. In vitro and ex vivo uptake of glutathione (GSH) across the intestinal epithelium and fate of oral GSH after in vivo supplementation. J. Agric. Food Chem. 2014, 62, 9499-9506. [CrossRef]

44. Yang, L.; Xu, F.; Zhang, M.; Shang, X.Y.; Xie, X.; Fu, T.; Li, J.P.; Li, H.L. Role of LncRNA MALAT-1 in hypoxia-induced PC12 cell injury via regulating p38MAPK signaling pathway. Neurosci. Lett. 2018, 670, 41-47. [CrossRef] [PubMed]

45. Tong, Z.-Y.; Yan, X.-P.; Li, S.-X.; Zhou, J.; Cai, G.X.; Zheng, Q.Y.; Huang, D. Isolation and Identification of Oxyresveratrol in Mulberry Branch. Sci. Seric. 2011, 37, 0948-0951. [CrossRef]

46. Guo, Y.X.; Bai, H.D.; Zhang, Z.Q. The Resveratrol Withdraws in the Medicine Mulberry. Sichuan Food Ferment. $2007,43,24-27$.

47. Miao, J.; Liao, W.; Kang, M.; Jia, Y.; Wang, Q.; Duan, S.; Xiao, S.; Cao, Y.; Ji, H. Anti-fatigue and anti-oxidant activities of oyster (Ostrea rivularis) hydrolysate prepared by compound protease. Food Funct. 2018, 9, 6577-6585. [CrossRef] [PubMed]

48. Chou, C.H.; Tsai, M.S.; Lu, H.Y.; Chang, C.K.; Cheng, K.C.; Jhan, M.H.; Hsieh, C.W. Enzymatic hydrolysates obtained from Trametes versicolor polysaccharopeptides protect human skin keratinocyte against AAPH-induced oxidative stress and inflammatory. J. Cosmet. Dermatol. 2019, 18, 2011-2018. [CrossRef] [PubMed] 